\title{
ТЕОРЕТИКО-МЕТОДОЛОГІЧНІ ЗАСАДИ ОЦІНКИ ЕФЕКТИВНОСТІ ІНФОРМАЦІЙНО- ПРОПАГАНДИСТСЬКОГО ЗАБЕЗПЕЧЕННЯ ЗБРОЙНИХ СИЛ УКРАЇНИ
}

У статті розглянуто теоретико-методологічні засади оцінки ефективності заходів інформаційно-пропагандистського забезпечення Збройних Сил України. Визначено понятійно-категоріальний апарат, структуру, принципи, функції оцінки ефективності інформаційно-пропагандистського забезпечення. Особлива увага зосереджена на розгляді методологічних основ оцінки виходячи з їі ролі та місця у структурі процесу інформаційно-пропагандистського забезпечення військ (сил) в умовах воєнно-політичного конфлікту. Визначено перспективи подальших досліджень, що полягатимуть у визначенні та обгрунтуванні підходів до вибору моделей та методів оцінки ефективності заходів інформаційно-пропагандистського забезпечення.

Ключові слова: інформаційно-пропагандистське забезпечення, оцінка ефективності, суб'єкт оцінки, об’єкт оцінки, структура оцінки, принципи, функції.

Постановка проблеми. Оцінка ефективності інформаційнопропагандистського забезпечення (далі - IПЗ), виступаючи основним інструментом контролю висновків про результативність процесу проведення заходів ІПЗ, в сучасних умовах набуває великого суспільного, морально-емоційного та стимулюючого значення. Вона $є$ тим “імпульсом зворотного зв'язку”, на підставі якого суттєво змінюється зміст стратегії і тактики удосконалення ІПЗ в Збройних Силах України на майбутній період.

Аналіз реальної військової практики показав, що сьогодні не існує типових методик розрахунку комплексної оцінки ефективності ІПЗ. Такий стан справ не дозволяє забезпечити повноту та об'єктивність оцінки. В багатьох випадках саме відсутність цих знань призводить до того, що оцінка здійснюється командирами на персонально-інтуїтивному рівні. Це зумовлює суб'єктивність оцінки та ії емоційне забарвлення, що у свою чергу, є причиною недооцінки ії практичної і теоретичної значущості.

Зозуля Олексій Сергійович, кандидат наук 3 державного управління, старший науковий співробітник Науково-дослідного центру гуманітарних проблем ЗС України, м. Київ.

(C) Зозуля О. С., 2018 
Ці обставини й визначають актуальність нашого дослідження, зобов'язуючи по-новому оцінити роль ІПЗ, що, в свою чергу, потребує своєчасного вирішення цілого ряду проблем як теоретичного, так і практичного характеру. Серед них особливої уваги заслуговує, на наш погляд, розгляд методологічних основ оцінки ефективності заходів ІПЗ. Вони набувають ще більшої актуальності з огляду на те, що за результатами соціологічного дослідження $(21,5 \%)$ респондентів у зоні проведення Антитерористичній операції вважають ефективність роботи щодо інформаційно-пропагандистського забезпечення особового складу частин та з'єднань низькою [11].

Вирішення цієї проблеми розширить межі наукового пізнання оцінки ефективності заходів ІПЗ; сприятиме розробці загальних методологічних принципів оцінки їх результативності; сприятиме виробленню єдиних, конкретних показників, за якими можна 3 найбільшим ступенем ймовірності судити про оптимальність функціонування системи ІПЗ в Збройних Силах України.

Аналіз останніх досліджень показав, що науковці переважно розглядали питання ефективності ІПЗ в Збройних Силах України через призму вдосконалення структури системи управління IПЗ в ЗСУ та оптимізації процесу організації і проведення заходів ІПЗ в окремих частинах і з'єднаннях $[8 ; 9 ; 13 ; 14 ; 18 ; 19 ; 25]$. Разом 3 тим, незважаючи на значну кількість робіт, в яких розглядаються актуальні питання підвищення ефективності IПЗ, поза увагою дослідників як воєнних, так і з інших галузей науки залишилися питання оцінки ефективності заходів ІПЗ як окремого інтегрального механізму системи інформаційно-психологічного забезпечення Збройних Сил України.

Метою статmі є розгляд теоретико-методологічних засад оцінки ефективності заходів інформаційно-психологічного забезпечення у Збройних Силах України.

Виклад основного матеріалу. Оцінка ефективності це важливий елемент системи IПЗ, він дозволяє визначити рівень результативності і впливу, комплексу заходів ІПЗ, і проводиться з метою вибору найбільш оптимального варіанта їх реалізації або способу вдосконалення.

Завдяки оцінці можна виявити так звані “критичні точки”, моменти, що здійснюють вирішальний вплив на ефективність заходів; в подальшому, здійснюючи коригуючий вплив саме на ці 
точки, організатори ІПЗ і командири зможуть домогтися суттєвих позитивних змін у свідомості та поведінці особового складу, тим самим заощадивши сили, час і ресурси.

Оцінка допомагає ідентифікувати реальний стан справ, визначити шляхи закріплення успіхів і виправлення недоліків. Під час планування і проведення оцінки ставляться конкретні питання, проводиться систематичний збір інформації 3 різних каналів, що входять до системи ІПЗ.

Дослідження теоретико-методологічних аспектів оцінки ефективності ІПЗ в першу чергу, об`єктивно, потребує розкриття значення ключових термінів і понять та їх співвідношення. Категоріальний апарат проблематики, що розглядається, складається з таких основних категорій (понять), як “ефективність”, “оцінка" та “оцінка ефективності".

Почнемо 3 найбільш загального i найбільш складного 3 “ефективності”. "Ефективність” є одним 3 ключових понять теорії систем, про що свідчать численні дослідження [4-6; 16; 21; 26]. В ході цих досліджень було доведено, що ефективність являє собою головний інваріант дії складної системи, що визначає іiі існування, перспективу розвитку і місце в надсистемі [6], та визначені іiі основні властивості [16].

На думку філософа М.Н. Андрющенко, “практика використання поняття “ефективність" показує, що ефективність виступає мірою можливості, але не будь-якої, а тієї, яка відображає мету людини, реалізує іiі ідею, тобто ефективність є міра можливості 3 точки зору іiі близькості до найбільш доцільного, необхідного (потрібного) людині результату. Більш точно, мова йде про близькість до мети в їі оптимальному вираженні” [1, с. 45-46].

Історія показує, що першою сферою використання та розробки поняття ефективності була економіка. В економічній літературі поняття “ефективність” розглядається як визначення ступеня досягнення певної мети, реалізації потенційної можливості, виконання завдання [3].

У сучасній теорії і практиці соціальної роботи це поняття має декілька значень [20, с. 41]: Ефективність в сенсі продуктивності, економічності - це показник ефективності діяльності, що відображає суму результатів на одиницю витрат. Чим менші ресурсовитрати на досягнення запланованих результатів, тим вище ефективність. 
Ефективність в сенсі дієвості - це здатність досягати ефекту (результату) деяких дій, який не завжди може бути виміряний за допомогою кількісних показників.

Ефективність в сенсі результативності, оптимальності - це здатність досягнути наміченого результату в бажаному обсязі. Цей вид ефективності фокусується на досягненні ефекту як такому, а не на ресурсах, витрачених на його досягнення.

Ефективність як управлінська категорія розглядається як результативність функціонування системи і процесу управління, як результат взаємодії керованої і керуючої систем, тобто інтегрований результат компонентів управління [22]. Ефективність показує, якою мірою керуючий орган реалізує цілі, досягає запланованих результатів.

Із зазначеного вище стає зрозуміло, що найбільш коректним $\epsilon$ визначення ефективності як ступеня відповідності можливих або отриманих результатів необхідним або бажаним [26]. Іншими словами, ефективність являє собою ступінь відповідності результатів функціонування системи цілям ії діяльності.

Запит на підвищення ефективності ІПЗ визначив значення “оцінки” як обов'язкового компонента. Зв'язок оцінки 3 ефективністю особливо підкреслюється Ж. Кенелом. Оцінка як діяльність неминуче виникає для аналізу результатів і ефектів діяльності [2; 23].

За визначенням $\mathrm{OOH}$, оцінка - це найбільш системне і неупереджене вивчення будь-якої діяльності, проекту, програми, стратегіï, політики, теми, сектора, галузі діяльності, роботи організації і т.п. Оцінка розглядає очікувані й отримані результати, процеси, контекст і причинно-наслідкові зв'язки, щоб зрозуміти, що було досягнуто, а що ні. Завдання оцінки - визначити, наскільки діяльність відповідає ситуації, наскільки ця діяльність результативна, ефективна і стійка, і який вплив вона здійснює. Висновки і рекомендації оцінки базуються на надійних і достовірних фактичних даних. Це дозволяє оперативно використовувати висновки і рекомендації оцінки для прийняття рішень [15, с. 5].

В контексті нашого дослідження та враховуючи все сказане вище, під поняттям “Оцінка" ми будемо розуміти процес формулювання і пошуку відповідей на важливі питання про ефективність діяльності.

Що стосується “Оцінки ефективності”, то існує різне розуміння даного поняття. В системній теорії оцінка ефективності $€$ 
найважливішим елементом аналізу. Відповідне значення практики оцінки ефективності як необхідного заключного етапу діяльності визначається в [2, с. 14].

Роль і функція цього етапу полягають не тільки в ретроспективному аналізі результатів, але і в коригуванні та розробці перспективних планів подальшої діяльності. Представляючи зворотній зв'язок для суб'єкта, що приймає рішення, оцінка ефективності детермінує характер і важливі ознаки майбутніх управлінських рішень.

Оцінка ефективності діяльності полягає в оцінці здібностей до досягнення поставлених цілей, виконання завдань і реалізації планів в повному обсязі 3 необхідною якістю у встановлений термін при оптимальному використанні організаційних, кадрових, фінансових, інформаційних та інших ресурсів.

Таким чином оцінка ефективності - це експертиза організаційного процесу діяльності, аналіз причин відхилень в іï реалізації від намічених спочатку цілей.

3'ясувавши суть і основні визначення категорій та понять нашого дослідження, тепер з'ясуємо, яким чином вони повинні використовуватися в прикладному їх застосуванні щодо сфери інформаційно-пропагандистського забезпечення. Інакше кажучи, дамо визначення таким поняття, як “ефективність ІПЗ”, “оцінка ефективності ІПЗ” та визначимо основні методологічні підході до здійснення цього специфічного и складного виду діяльності.

Грунтуючись на єдиному офіційно затвердженому в Тимчасовій настанові $з$ морально-психологічного забезпечення підготовки та застосування Збройних Сил України, визначенні поняття IПЗ [23], ми можемо дати визначення поняття “ефективність ІПЗ” в його широкому розумінні.

Ефективність ІПЗ - ступінь відповідності (досягнення) результатів діяльності органів військового управління, командувачів, командирів (начальників), службових осіб органів МПЗ запланованим цілям із формування в особового складу стійкої мотивації до збройного захисту територіальної цілісності, державного суверенітету України, адекватного розуміння воєнно-політичної обстановки, СПО, завдань, покладених на війська (сили), умов та особливостей їх виконання.

У вузькому розумінні ефективність ІПЗ розглядається як зміна найважливіших параметрів поведінки особового складу під впливом заходів ІПЗ. 
3 поняттям “Оцінка ефективності ІПЗ” ситуація складніша, оскільки для його визначення спершу необхідно визначити оцінку, саме якої ефективності ІПЗ ми будемо досліджувати. У зв'язку 3 тим, що ефективність ІПЗ можна представити через ряд ії складових (ефективність системи управління і забезпечення ІПЗ ЗСУ; ефективність внутрішньо-комунікаційної роботи; ефективність військово-патріотичної роботи; ефективність культурологічної роботи; ефективність забезпечення ТЗП; ефективність впливу заходів ІПЗ), необхідно окреслити методологічні [24] засади оцінки ефективності ІПЗ, що дозволять, по-перше, уникнути деякої однобічності при розгляді ефективності, по-друге, в ході оціночної діяльності забезпечать отримання об'єктивних результатів оцінки.

Вивчення цих питань вимагає звернення до засобів філософії, насамперед аксіології. Як вже було зазначено вище, оцінка $\epsilon$ суб'єктивним засобом вираження цінності об'єкта. Засадами для визначення ціннісної предметності ефективності ІПЗ постають потреби суб'єкта ІПЗ у відповідному рівні формування моральнобойових якостей військовослужбовців, які дозволили б йому якісно виконувати свої службові обов'язки.

Так, сучасний етап становлення Збройних Сил України повинен змінити і потреби суб'єктів ІПЗ. Проте аналіз реальної практики доводить, що цей процес йде повільно. Командири різних рівнів ще глибоко не усвідомили необхідність приведення змісту процесу проведення інформаційно-пропагандистських заходів у відповідність 3 характером сучасного військово-політичного конфлікту.

Основним об'єктом оцінки ефективності ІПЗ виступає конкретний військовослужбовець (група військовослужбовців) 3 уже сформованим спектром і рівнем розвитку морально-етичних й бойових якостей та реальний процес IПЗ. Суб'єктом оцінки є, по перше, сам об'єкт ІПЗ, по-друге, всі, хто наділені правом оцінки (командири різних ланок, перевіряючі). У Збройних Силах України суб'єктами оцінки ефективності ІПЗ є: органи військового управління, командири, штаби, службові особи органів МПЗ усіх рівнів, військові капелани, громадські (волонтерські) організації (за згодою) тощо. Всі вони вирішують єдині загальні завдання, домагаються єдиної цілі ІПЗ і відповідно оцінюють ефективність iiі досягнення. 
Отримані знання про предмет оцінки ефективності IП3, іï принципи, об'єкт і суб'єкт оцінки дозволяють перейти до аналізу iii структури. Поняття структури оцінки ефективності ІПЗ спрямоване не лише на визначення iї елементного складу, а й на виявлення стійких взаємовідносин елементів: відношень взаємодії, будови, функціонування, розвитку та ін.

Таке розуміння сутнісних рис і структури оцінки ефективності ІПЗ дає можливість дати наступне іiі визначення. Оцінка ефективності ІПЗ - це специфічна діяльність (процес) їі суб’єкта, в результаті якої відбувається порівняння якості проведених заходів ІПЗ з оціночним еталоном задоволення потреби в формуванні у військовослужбовців такого спектра і рівня розвитку морально-правових та бойових якостей, які дозволили б їм бездоганно виконувати свій військовий обов'язок.

Знання оцінки ефективності ІПЗ не може бути обмежено тільки розумінням ії сутностей та особливостей. Реальний процес оцінки ефективності ІПЗ $є$ більш складним і 3 необхідністю ставить питання всебічного його вивчення. Дане положення орієнтує на пізнання інших атрибутів оцінки ефективності ІПЗ. До них належать принципи, функції, моделі, підходи, методи і критерії оцінки ефективності ІПЗ, на основі яких вона здійснюється.

Всі атрибути оцінки ефективності ІПЗ у своїй взаємодії складають певну системну структуру. Тому під час дослідження оцінки ефективності ІПЗ доцільно застосовувати системодіяльнісний підхід, що допоможе з'ясуванню вихідних принципів iï здійснення, оскільки сама практика показує, що справа ця надто складна. Практика проведення оцінки ІПЗ показала, що, поперше, суб'єкти ІПЗ керуються вельми обмеженим числом принципів, а деякі з них взагалі не виразно їх уявляють. По-друге, відсутня чітка система принципів оцінки ефективності ІПЗ.

Методологічні принципи оцінки ефективності ІПЗ є системою всезагальних філософських, загальнонаукових i специфічних правил i ціннісних норм. Серед загальнонаукових принципів найбільш важливими, стрижневими принципами оцінки ефективності ІПЗ є принципи:

науковості - використання наукових методів, таких як аналіз, синтез, класифікація, що дозволяють досягти більшої повноти інформації про досліджуваний об'єкт;

об'єктивності - орієнтує на вибір і застосування оціночних методик, критеріїв і показників, які максимально точно та адекватно дозволяють судити про ефективність процесу або заходів IПЗ; 
системності - означає систематичність оцінки ефективності; визначення ефективності 3 урахуванням дії всіх внутрішніх і зовнішніх факторів, повторюваність оціночних процедур з певною часовою частотою; облік і взаємозв'язок всіх видів ефективності;

комплексності - передбачає комплексне використання різних джерел інформації, оціночних методик, критеріїв і показників;

безперервності - означає визначення ефективності ІПЗ на всіх етапах його функціонування;

технологічності - вимагає реалізації простих, економічних, зручних, зрозумілих, доступних технологій і методик оцінки ефективності; використання технічних, апаратних, комп'ютерних, програмних засобів.

Важливим атрибутом оцінки ефективності ІПЗ постають іiі функції. До найважливіших функцій оцінки ефективності IПЗ відносять: регулятивну, індикативну, прогностичну, нормативну та аксіологічну.

Аксіологічна функція оцінки ефективності ІПЗ - $є$ основною, визначальною iї функцією. Оцінка ефективності ІПЗ ставить за кінцеву мету виявлення значущості, цінності як наявних у об'єкта спектра морально-бойових і психологічних якостей, рівня їх розвитку, так і самого процесу ІПЗ.

Регулятивна функція оцінки проявляється в тому, що здійснює регуляцію відповідності цілей, змісту і результатів процесу ІПЗ.

Індикативна функція оцінки ефективності ІПЗ дозволяє відстежувати відношення між суб'єктом і об'єктом ІПЗ, оскільки в оцінці знаходить своє відображення не тільки результат ІПЗ, за яким ми робимо висновок про його ефективність, а й розкривають себе, цілі, засоби процесу ІПЗ.

Прогностичну функцію оцінки ефективності ІПЗ реалізувати досить складно. Адже цей прогноз повинен відповідати прояву реального рівня розвитку морально-бойових якостей в умовах воєнного часу. Звідси - підвищена вимогливість до точності прогнозу у необхідному рівні розвитку морально-бойових i психологічних якостей як результату оцінки.

Нормативна функція оцінки ефективності ІПЗ полягає в тому, що в ній виражена міра оцінюваних морально-бойових і психологічних якостей та її відхилення від відповідної норми.

Типологізувати оцінку ефективності ІПЗ можна за наступними засадами: за складовими IП3; за функціями IП3; за формами IПЗ; за методами ІПЗ; за засобами ІПЗ; за суб'єктом оцінки; за цілями (змістом) ІПЗ. 
Типологізація оцінки за складовими ІПЗ. До основних складових ІПЗ належать: внутрішньо-комунікаційна робота; військово-патріотична робота; культурологічна робота; забезпечення ТЗП. Типологізація оцінки ефективності ІПЗ у функціональному плані за основу поділу має функції, які здійснює ІПЗ світоглядна, комунікативна, інформаційна, пропагандистська, контрпропагандистська, роз'яснювальна, захисна, виховна, логікогносеологічна, мобілізуюча, демпфуюча, управління [10, с. 44-55].

Типологізація оцінки за формами ІПЗ (усна інформаційнопропагандистська діяльність (лекції, бесіди, доповіді, повідомлення, перекази, читання, інформування, тематичні вечори, вікторини, диспути, заняття з гуманітарної підготовки, консультації, обговорення тощо); застосування та розповсюдження друкованих інформаційно-пропагандистських матеріалів (виставки, покази, читання матеріалу, ілюстрації, самостійне вивчення, обговорення, вікторини, ярмарки, куточки інформації - правової, політичної, військово-політичної, воєнно-політичної, історичної тощо); наочна агітація та пропаганда (інформаційні бюлетені, бойові листки, листівки-блискавки, стінні газети підрозділів, фотогазети, стенди, плакати, діаграми, гасла і заклики тощо); застосування засобів радіо, телебачення та кіно (перегляд і прослуховування інформаційних, військово-патріотичних, інформаційно-пізнавальних та інших радіо, телевізійних i кінопрограм у передбачений розпорядком дня час, їх обговорення, використання засобів радіо, телебачення, кіно, комп'ютерів під час проведення заходів усної інформаційно-пропагандистської діяльності) [33]. Даний вид оцінки дасть змогу з'ясувати, по-перше, яка із форм ІПЗ має найбільш впливову дію на особовий склад загалом; по-друге, яка 3 форм найбільш ефективна в залежності від умов (мирний час, особливий період, бойові дії) і в залежності від цільової аудиторії (командний склад, військовослужбовці строкової служби, контрактники, працівники ЗСУ тощо).

Типологізація оцінки за методами ІПЗ. Основні методи інформаційно-пропагандистського забезпечення $\epsilon$ словеснонаочні, пояснювально-ілюстративні (інформаційно-рецептивні) та пояснювально-спонукальні методи [10, с. 28-31]. Типологізація оцінки за засобами ІПЗ. Тимчасова настанова 3 морально-психологічного забезпечення у Збройних Силах України до засобів IПЗ відносить: штатні, штатно-табельні та не табельні, придатні до 
використання технічні засоби пропаганди (далі - ТЗП), а також засоби військових та цивільних ЗМІ (телерадіокомпаній, телерадіостудій, редакцій та видавництв тощо), типографій, центрів військово-музичного мистецтва, військових оркестрів, ансамблів, закладів культури та іншої місцевої інфраструктури [23].

Типологізація оцінки за суб'єктом оцінки виходить з ідеї, що в широкому розумінні суб'єкт оцінки може виступати в якості індивіда та в якості колективу. Відтак, і оцінка може бути індивідуальною (оцінка командира), колективною (оцінка первинного військового колективу, експертна оцінка, суспільна і т.д.), безпосередньою (оцінка командира відділення, командира взводу, командира роти) і опосередкованою (оцінка представника командування, ГУМПЗ, особи, що інспектує і т.д.). Типологізація оцінки за цілями (змістом) грунтується на оцінці ефективності досягнення головних цілей ІПЗ (формування в особового складу системи моральних якостей, норм, принципів і переконань, розвиток етичних мотивів свідомого і сумлінного виконання військового обов'язку).

У процесі проведення оцінки ефективності велике значення має правильний вибір структури або дизайну оцінки. Структура оцінки, або дизайн оцінки, - це методична основа процесу оцінки, яка формується відповідно до її цілей і завдань.

Висновки. На основі аналізу проблематики оцінки ефективності заходів ІПЗ зазначимо, що лише виключно на науковій основі, об'єктивно оцінюючи процес і результати IПЗ, можна правильно вибудувати систему пропагандистських впливів окремо на кожного військовослужбовця та особовий склад загалом, заздалегідь прогнозуючи той чи інший результат, своєчасно вносити в нього необхідні корективи.

3 питань організаційних заходів щодо вдосконалення оцінки ефективності ІПЗ було б доцільно:

- рекомендувати створення єдиної системи інформаційного забезпечення, що передбачатиме скоординоване ведення IПЗ на основі попередньо вироблених уніфікованих підходів;

- рекомендувати впровадження “Комплексної цільової програми вдосконалення оцінки ефективності заходів ІПЗ” і методику оцінки рівня підготовленості офіцера для здійснення інформаційнопропагандистської діяльності в підрозділі;

- рекомендувати в процесі діагностики та оцінки еффективности заходів ІПЗ використовувати запропоновані в даному дослідженні критерії та показники; 
- продовжувати роботу із розробки методики оцінки ефективності ІПЗ;

- приділяти більше уваги забезпеченню ТЗП, їх використання в повному обсязі в ході проведення заходів ІПЗ;

- ініціювати створення та вдосконалення навчально-матеріальної бази для якісного проведення заходів ІПЗ;

- найбільш повно використовувати можливості клубів і бібліотек військової частини, гарнізонного Будинку офіцерів, засобів масової інформації в інтересах підвищення ефективності ІПЗ;

- організаторам заходів ІПЗ приділяти більше уваги для підготовки занять, постійно вдосконалювати свої методичні навички;

- запровадити інститут “особистої відповідальності” організаторів заходів ІПЗ за теоретичний і методичний рівень проведених занять.

В зв'язку з актуальністю проблеми оцінки ефективності заходів ІПЗ перспективи подальших досліджень вбачаються у визначенні та обгрунтуванні підходів до вибору моделей та методів оцінки ефективності заходів інформаційно-пропагандистського забезпечення Збройних Сил України.

1. Андрющенко М.Н. Понятие эффективности и его философский смысл / М.Н. Андрющенко // Учен. записки кафры обществ. наук вузов г. Ленинграда. - Л.: Изд-во ЛГУ, 1971. - Вып. 12. - С. 42-49.

2. Бочарова А.К. Механизм оценки эффективности деятельности органов исполнительной власти субъектов Российской Федерации: препринт WP14/2012/05 [Текст] / А. К. Бочарова; Нац. исслед. ун-т "Высшая школа экономики”. М.: Изд. дом Высшей школы экономики, 2012. -68 с.

3. Галухин A.B. Оценка эффективности бюджетных расходов на реализацию долгосрочных целевых программ: теоретико-методологический аспект [Электронный ресурс] // Современные научные исследования и инновации. - 2014. № 1. - Режим доступа: http://web.snauka.ru/issues/ 2014/01/30882 (26.12.2016).

4. Дружинин В.В. Вопросы военной системотехники / В.В. Дружинин, Д.С. Конторов. - М.: Воениздат, 1976. - 224 с.

5. Дружсинн В.В. Проблемы системологии / В.В. Дружинин, Д.С. Конторов - М.: Сов. радио, 1976. - 296 с.

6. Дружинин В.В. Основы военной системотехники / В.В. Дружинин, Д.С. Конторов - М.: МО СССР, 1983. - 416 с.

7. Зонь В.В. Організація інформаційно-пропагандистського забезпечення особового складу Збройних Сил України: Навчальний посібник / В.В. Зонь, С.О. Кубіцький, В.Г. Слонімський, М.В. Великожон. - К.: Видавничо-поліграфічний центр „Київський Університет”, 2007. - 225 с. 
8. Інформаційно-комунікативні технології в гуманітарній сфері Збройних Сил України: досвід, проблеми, перспективи: підручник / В.І. Осьодло, В.В. Стасюк, В.П. Шевчук та ін.; За заг. ред. В.Г. Радецького. - К.: НАОУ, 2007.

9. Інформаційно-пропагандистське забезпечення військ (сил) в умовах воєнно-політичного конфлікту: звіт про НДР (заключний) / Науково-дослідний центр гуманітарних проблем Збройних Сил України; кер. О.І. Холох; викон.: В.Л. Топальський [та ін.]. - К., 2017. - 318 с. - № ДР 0117U002429. - Інв. № 0217U003481.

10. Інформаційно-психологічний вплив противника на особовий склад Збройних Сил України, який бере участь у антитерористичній операції на території Донецької та Луганської областей: Аналітичний звіт за результатами соціологічного опитування. - К.: НДЦ ГП ЗСУ, 2016. - 58 с.

11. Кенел Ж. Оценка и аудит программ: сходства и различия // Оценка программ: методология и практика / [под ред. А.И. Кузьмина, Р. О. Салливан, Н.А. Кошелевой]. М.: Престо-РК, 2009. - С. 28-34.

12. Малюга В.М. Особливості інформаційно-комунікативних процесів у військових колективах: навч. посібник / В.М. Малюга. - К.: ВГІ НАОУ, 2002.

13. Малюга В.М. Основи інформації та інформаційнопропагандистського забезпечення / В.M. Малюга, О.Л. Ходанович. - К.: ВГІ НАОУ, 2003.

14. Нормы оценки в системе ООН [Электронный pecypc] / Группа Организации Объединенных Наций по оценке (ГООНО), 2005. - 12 с. - Режим доступа: http://www.uneval.org/papersandpubs/ documentdetail.jsp?doc_id=21 (26.12.2016).

15. Николаев В.И. Системотехника: методы и приложения / В.И. Николаев, В.М. Брук. - Л.: Машиностроение, Ленингр. отд-ние, 1985. - 199 с.

16. Організація інформаційно-пропагандистського забезпечення в підрозділі [Електронний ресурс]. - Режим доступу: http://i-bictashev.narod.ru/index/0-78 (26.12.2016). - Назва 3 екрана.

17. Осьодло B.I. Порадник офіцеру з питань ІПЗ: Навчально-методичний посібник / B.I. Осьодло, В.І. Петрович, В.І. Савінцев. - К.: НАОУ, 2004.

18. Осьодло B.I. Основи інформації і комунікації: Навч. посібник / В.І. Осьодло, О.П. Позняков. - К.: НАОУ, 2006.

19. Оценка эффективности деятельности учреждений социальной поддержки населения / [Под ред. П.В. Романова и Е.Р. Ярской-Смирновой] // Серия "Научные доклады: независимый экономический анализ”. - М.: Московский общественный научный фонд; Центр социальной политики и гендерных исследований, 2007. - 234 с. 
20. Оценка эффективности огневого поражения ударами ракет и огнем артиллерии. - СПб.: “Галлея Принт", 2006. -424 c.

21. Сметанюк O.A. Етимологія категорії “ефективність управління організацією" / О.А. Сметанюк, О.П. Сочівець // Актуальні проблеми економіки. - 2009. - № 8(98). - С. 136-140.

22. Тимчасова настанова 3 морально-психологічного забезпечення підготовки та застосування Збройних Сил України / Наказ Генерального штабу Збройних Сил України від 14 березня 2016 року. - К.: ГШ МОУ, 2016.

23. Философский энциклопедический словарь. - М.: Сов. Энциклопедия, 1983.

24. Ходанович О.Л. Інформаційні технології та їх роль у системі інформаційно-пропагандистського забезпечення Збройних Сил України: Навч. посібник / О.Л. Ходанович К.: ВГІ НАОУ, 2002.

25. Червоный A.A. Вероятностные методы оценки эффективности вооружения / А.А. Червоный, В.А. Шварц, А.П. Козловцев, В.А. Чобанян. - М.: Воениздат, 1979. - 95 с.

Надійшла до редколегії 25.12.2017 p.

Рецензент: Бураков Ю.В., кандидат історичних наук, доцент, провідний науковий співробітник Наукового центру Національної академії сухопутних військ імені гетьмана Петра Сагайдачного, м. Львів

\section{Zozulya Alexsiy \\ THEORETICAL AND METHODOLOGICAL PRINCIPLES OF EFFECTIVENESS EVALUATION OF INFORMATION AND PROPAGANDA SUPPORT OF THE UKRAINIAN ARMED FORCES}

The article deals with theoretical and methodological principles of the effectiveness evaluation of measures for information and propaganda support of the Ukrainian Armed Forces. It defines the conceptual-categorical apparatus, structure, principles, functions of efficiency evaluation of information and propaganda support. Particular attention is paid to the examination of the methodological basis of the evaluation, based on its role and place in the structure of the process of information and propaganda support of troops in the military-political conflict. The article determines prospects for further research which will consist in defining and grounding approaches to the selection of models and methods for effectiveness evaluation of promotional activities.

Key words: information and propaganda support, evaluation of effectiveness, subject of evaluation, object of evaluation, evaluation structure, principles, functions. 